\title{
Implication of the training ad continuing education process for the interprofessional performance
}

\author{
Implicação do processo de formação e educação permanente para atuação interprofissional \\ Implicación del proceso de formácion e educación continua para la actuación interprofesional
}

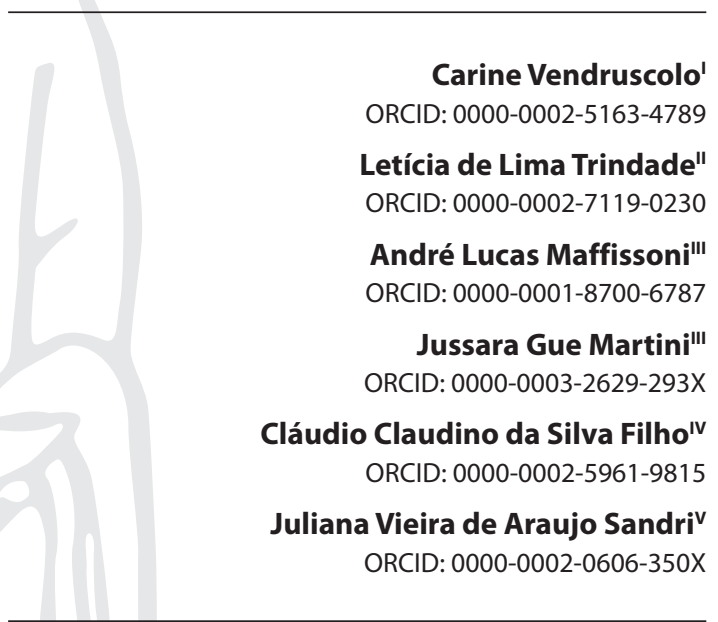

'Universidade do Estado de Santa Catarina. Chapecó, Santa Catarina, Brazil. "Universidade Comunitária da Região de Chapecó. Chapecó, Santa Catarina, Brazil.

"' Universidade Federal de Santa Catarina. Florianópolis, Santa Catarina, Brazil.

"v Universidade Federal da Fronteira. Chapecó, Santa Catarina, Brazil.

${ }^{v}$ Universidade do Vale do Itajaí. Itajaí, Santa Catarina, Brazil.

How to cite this article: Vendruscolo C, Trindade LL, Maffissoni AL, Martini JG, Silva Filho CC, Sandri JVA. Implication of the training ad continuing education process for the interprofessional performance. Rev Bra Enferm. 2020;73(2):e20180359. doi: http://dx.doi.org/10.1590/0034-7167-2018-0359

Corresponding Author:

Carine Vendruscolo

E-mail: carine.vendruscolo@udesc.br

EDITOR IN CHIEF: Dulce Aparecida Barbosa ASSOCIATE EDITOR: Alexandre Balsanelli

Submission: 05-25-2018Ａpproval: 03-13-2019

\section{ABSTRACT}

Objetives: to analyze the implication of the training/continuing education process of professionals of the Expanded Nucleus of Family Health and Basic Care (Portuguese acronym: Nasf-AB) for their interprofessional performance. Methods: a qualitative case study performed with Nasf-AB teams representative of four macro-regions of health of the state of Santa Catarina. Participation of 43 professionals, who answered collective interviews. The results were later submitted to thematic analysis. Results: the training is strongly influenced by the Biomedical Model, which acts as an obstacle to interprofessional performance, given the challenges in the daily routine of Nasf-AB professionals. Continuing education emerges as a potential for the successful collaborative work among teams, and between the teams and Family Health professionals. Final considerations: there are important limits in the training of professionals. However, the constant interprofessional development promoted by strategies of continuing education contributes to broaden the support and collaborative practices that qualify services and strengthen Basic Care. Descriptors: Primary Health Care; Family Health; Health Personnel; Continuing Education; Training of Human Resources in Health.

\section{RESUMO}

Objetivos: analisar a implicação do processo de formação/educação permanente dos profissionais do Núcleo Ampliado de Saúde da Família e Atenção Básica (Nasf-AB) para a sua atuação interprofisisonal. Métodos: estudo de caso de abordagem qualitativa, realizado com equipes de Nasf-AB representativas de quatro Macrorregiões de Saúde do Estado de Santa Catarina. Participação de 43 profissionais que responderam entrevistas coletivas. Os resultados foram posteriormente submetidos à análise temática. Resultados: identificou-se marcante influência do Modelo Biomédico na formação, que funciona como obstáculo para a atuação interprofissional frente aos desafios no cotidiano do Nasf-AB. A educação permanente emerge, marcantemente, como potência para o sucesso do trabalho colaborativo entre as equipes e destas com os profissionais da Saúde da Família. Considerações finais: há limites importantes na formação dos profissionais. Contudo, o desenvolvimento interprofissional constante promovido pelas estratégias de educação permanente contribui para ampliar o apoio e as práticas colaborativas que qualificam os serviços e fortalecem a Atenção Básica. Descritores: Atenção Primária à Saúde; Saúde da Família; Pessoal de Saúde; Educação Continuada; Capacitação de Recursos Humanos em Saúde.

\section{RESUMEN}

Objetivos: analizar la implicación del proceso de formación/educación continua de los profesionales del Núcleo Ampliado de Salud de la Familia y Atención Básica (Nasf-AB) en su actuación interprofesional. Métodos: estudio de caso cualitativo realizado con equipos de Nasf-AB representativos de cuatro Macroregiones de Salud del Estado de Santa Catarina. Participación de 43 profesionales que respondieron a entrevistas colectivas. Los resultados fueron posteriormente sometidos al análisis temático. Resultados: hubo notable influencia del Modelo Biomédico en la formación, que funciona como obstáculo para la actuación interprofesional frente a los desafíos en el cotidiano del Nasf-AB. La educación continua emerge como potencia para el éxito del trabajo colaborativo entre los equipos, y de los equipos con los profesionales de la Salud de la Familia. Consideraciones finales: hay límites importantes en la formación de los profesionales. Sin embargo, el desarrollo interprofesional constante promovido por las estrategias de educación continua contribuye a ampliar el apoyo y las prácticas colaborativas que califican los servicios y fortalecen la Atención Básica. Descriptores: Atención Primaria en la Salud; Salud de la Familia; Personal de Salud; Educación Continua; Capacitación de Recursos Humanos en Salud. 


\section{INTRODUCTION}

At the national and world level, the experience initiated with the Sanitary Reform that culminated in the Unified Health System (Brazilian SUS) has aroused interest given the extent of changes and number of individuals and institutions involved. The decisive role of human resources is to broaden the access to services and transform the care model ${ }^{(1)}$.

In order to form democratic citizens with knowledge, skills and conduct in line with a qualified and integrated health system, it is necessary to provide experiences of relationships and recognize the different perspectives and places in professional training ${ }^{(2)}$. From this perspective, learning in the health area is influenced by the context of practice, hence the need to respect changes in the work process and consider the balance between technical excellence and social relevance.

The proposed interdisciplinary work of the Expanded Nucleus of Family Health and Basic Care (Portuguese acronym: Nasf-AB) requires differentiated training, since it is based on the integration of professionals from different specialties and general practitioners who work in the Basic Care team (Portuguese acronym: eAB) or the Family Health Strategy (FHS), the structures that operationalize this level of care through support actions and by sharing health practices and knowledge ${ }^{(3)}$.

Professionals of various specialties form the Nasf-AB teams. Their work tools are the matrix support, expanded clinic and unique and collective therapeutic projects. The objective of these teams is to strengthen the Family Health teams (Portuguese acronym: eSF) with expansion of healthcare and health promotion actions, and support the coordination of Basic Care (Portuguese acronym: AB). The model also contributes to the articulation and regulation of access to the Health Care Network (Portuguese acronym: RAS) with organization, and above all, referrals to medium complexity. This stimulates comprehensive, integral and resolutive care, since the diversity of professions that can be integrated into the teams provides that Nasf-AB teams perform activities anchored in knowledge of the nuclei of each profession, and collective health knowledge ${ }^{(4)}$. Making this action interprofessional involves collaboration among professionals, so they re-evaluate the relationships between their professions, invest in mutual understanding and explore forms of combining their expertise in order to improve service delivery, user safety and quality of care ${ }^{(5)}$.

The network based on matrix support values the expanded conception of the health-disease process, the dialogue and interaction between professionals ${ }^{(6)}$. The concept of work inspired by the Paidéia model aims to favor the democratization of management in organizations by forming organized collectives and encouraging subjects' participation in the management of their work processes. This performance criticizes the referral and counter-referral model by considering this organizational logic as vertical, hierarchical, bureaucratic, unproductive, and that it accentuates the difference of authority among professionals ${ }^{(7)}$. Therefore, it represents a proposal for the reformulation of traditional management mechanisms and focuses on the formation of people and social relationships. Interdisciplinary action encourages discussions of clinical cases, enables shared care among professionals in the health unit and community, and favors the construction of therapeutic projects. The support may also be based on intersectoral actions focused on health promotion, which requires adequate training in the field of collective health ${ }^{(6-7)}$. All these aspects can be even more resolute if supported by an interprofessional perspective. Interprofessional Education (IPE) is strategic because it stimulates the formation, the shared and interactive learning process with a view to collaboration and quality of health care, and is coherent with the strengthening needs of SUS ${ }^{(5)}$.

Although the Brazilian SUS is considered the largest employer in the health sector in the country, professional training remains directed to the traditional market demands and distant from the needs of changes and the integration of teaching-service-community. Traditional pedagogical concepts also collaborate in this sense, because they are based on transmitting pedagogies and critical and reflexive conceptions that take into account the social reality. The proposals of training institutions strengthen the incorporation of highly complex technological teaching at high costs with diagnostic and therapeutic practices, traditional models for selection of syllabus and evaluation, and emphasize the importance of specialties, i.e., typical of the biomedical model ${ }^{(8)}$. On the other hand, the reorientation of health education provides reflections on the need for teamwork, collaborative practices and interprofessional education. Its concept is linked to the notion of teamwork and negotiation of decision-making processes through the collective construction of knowledge and respect for the differences and singularities of nuclei of knowledge and practices in a dialogical way ${ }^{(9)}$.

A featured researcher and collaborators ${ }^{(10)}$ provoke reflections on interprofissisonal practices/performance and highlight four interconnected dimensions for their effective conduction: 1) the vision, which involves the common objectives of the teams; 2 ) internalization, evidenced in the awareness of professionals about their interdependence in the work process and consequent need for interaction and trust; 3 ) governance or leadership, which encourages the participation of all; and 4) formalization, which highlights the need for communication and well-structured flows for the teams' performance.

Considering these challenges, the interprofessional performance of Nasf-AB professionals can be substantial for the improvement of Basic Care. For this reason, managers and professionals need to be clear about which practices are under responsibility of the Nucleus and how they should be performed. In addition, there are several challenges in the praxis of Nasf-AB professionals and in their interaction with $\mathrm{eAB} / \mathrm{eSF}$, including those related to the training process ${ }^{(11)}$. The present study starts from the question: how does the training/continuing education of professionals influence the daily interprofessional practice of Nasf-AB teams?

\section{OBJECTIVES}

To analyze the implication of the process of formation/continuing education of Nasf-AB professionals for their interprofessional performance.

\section{METHODS}

\section{Ethical aspects}

The study was approved by the Research Ethics Committee. Participants were enlightened about details of the study, signed 
the informed consent form and were identified by the professional category, followed by the term Nasf-AB and a serial number representative of the original macro-region, and also the order number in case of repeated categories (eg, Physical Educator/ Nasf-AB1, Pharmaceutical1/Nasf-AB4, Pharmaceutical2/Nasf-AB4).

\section{Type of study}

This is an exploratory descriptive case study ${ }^{(12)}$ with the involvement of five Higher Education Institutions (HEls) responsible for collecting and analyzing data in all health macro-regions of the state of Santa Catarina (SC). This manuscript was developed from the problematization of partial results of the multicenter study: "Support Centers for Family Health: continuing education movements for the promotion of health through the social reality of the territory". The study was guided by the following problematizing question: how does the process of training/ continuing education of Nasf-AB professionals influence their interprofessional performance?

\section{Scenario and study participants}

Collective interviews were performed with five Nasf-AB teams representative of the macro-regions of the state that were more accessible for the HEls involved. Forty-three Nasf-AB professionals from five municipalities belonging to four health macro-regions of the state participated in the study. Participants were organized by their different professional categories as follows: seven social workers; seven physical educators; seven pharmacists; six physiotherapists; nine nutritionists; seven psychologists; and a speech-language pathologist. They were included according to availability on the day of data collection. The quantity of teams and professionals was defined by the criterion of data saturation.

\section{Production and organization of information}

Interviews lasted an average of two hours and were conducted by interviewer, rapporteur (made notes on profile and sequence of speakers) and supporters (they circulated around the room with recorders). The speeches were recorded and later transcribed. The information was produced from September to November 2017 in family health units or the HEls in a space defined by the teams and reserved for this stage of the investigation. Sessions were scheduled in advance to avoid any interference in the work dynamics of the teams.

\section{Analysis of information}

The thematic content analysis was adopted for interpretation of information ${ }^{(13)}$. Firstly, was performed the pre-analysis of the material produced through skim reading the transcriptions of speeches in order to constitute the corpus of data. Then, came the exploratory phase that resulted in the first coding to reach the understanding core of the text. The text was cut into registration units, from which emerged the following categories: a) Biomedical Model: marks in the training and obstacle to interprofessional performance; and b) Challenges in the daily life of Nasf-AB professionals: continuing education as a power for success.

\section{RESULTS}

The collective interviews included 43 Nasf-AB professionals, namely: social workers, physical educators, psychologists, physiotherapists, pharmacists, a speech-language pathologist and nutritionists.

\section{Biomedical Model: marks in the training and obstacle to interprofessional performance}

The dialogues enable reflections about the marks of the Biomedical Model in the work of professionals. It is still strongly focused on individual and curative care with little guidance for preventive practices and health promotion. For Nasf professionals, despite the changes in some professions, these marks are still visible in the attitude of teams and managers. Because of that, they sometimes feel invisible in the context of public/collective health and Basic Care:

I hold a bachelors' degree. I was trained with an awareness of what health would be, but far from understanding how public health works. Getting adjusted to this logic was complicated. (Physical educator/Nasf-AB1)

[...] there is a resistance related to the fact that "you have to attend", you cannot stay without the nurse, "God forbid you cancel the doctor's schedule!" There is a lot of this concern about the schedule, the service. (Social worker/Nasf-AB1)

Individual care is curative; and as we do not prioritize this care, they make us feel like [...] as if we didn't exist [Nasf-AB professionals], we are not important for the current management ... it's a setback, it's kind of sad. (Physiotherapist/Nasf-AB2)

The support to Basic Care teams of graduated general practitioners, including doctors and nurses, was a challenge for the practice of Nasf-AB professionals. In the work of the Nuclei, the clinical and care support was initially provided in a hegemonic way, given the lack of preparation for pedagogic practices of support that characterize the matrix organization. This reality has gradually changed over time, but there is still insecurity. Nasf professionals perceive themselves as educators when performing such attribution.

[...] I do not think the Nasf is prepared. We deal with professionals of the same level: nurses, doctors, and I do not think we are prepared to train the team, of course, when it comes to my area, yes, I can get here, talk a little bit, but I think there is lack [...] (Pharmacist/Nasf-AB2)

Nowadays, we see that professionals of the strategy [Family Health] analyze that we can help, that we are doing a job together with them, that it is not something apart. Obviously, there is always one or another who does not see it this way, but mostly, we notice they are understanding we are part of the process too, that we are there to contribute. (Speech-language pathologist/Nasf-AB4)

[...] I have never thought of myself as provider of continuing education [...] The matrix organization is to give education [...] (Social worker/Nasf-AB1) 
Nasf professionals reflect on their relationship with Family Health teams and draw attention to the need and importance of exchanging professional knowledge, even among the Nasf teams. In this context, they highlight the potential of the matrix organization:

[...] we need to be a little bit of each profession, I'm not a professional nutritionist or a pharmacist, but I have knowledge, depending on the subject, on the patients' needs, for providing guidance. (physical educator/Nasf-AB3)

We develop a lot of teamwork with Nasf itself and Nasf tools. What is the matrix organization? What is a shared consultation or a unique therapeutic project? [...] (Social worker/Nasf-AB5)

The theory differs a little from practice, but we have been working with the Family Health teams [eSF] mainly exchanging ideas in order to be the matrix support [...] (Nutritionist/Nasf-AB4)

Professionals emphasize that changes are already visible in the generalist focused training, which allows an adequate performance in collaborative practices and directed to the reality of the territory, as recommended by the Nasf-AB model. The aspects demanded in this assistance model emerged in the speeches, and they show training demands and pass through the capacity of collective and interprofessional work.

[...] I was talking to a friend, a physical education student, and she was in an internship program [...] and participated in a group with the Nasf people, commented about the matrix organization, territorialization, and I thought it was great, her opportunity of having this experience during formation. (Physiotherapist/Nasf-AB3)

[...] perhaps during our training, there was lack of practices encouraging teamwork, relationships [...] but this is changing, and we go after it, too! (Psychologist//Nasf-AB4)

Nasf professionals consider that the training process at undergraduate level has a deficit of contents and practices related to the performance as generalists in Basic Care with some variation from one course to another or between universities. This presupposes the need for continuing education movements in daily work. They emphasized the positive difference of the performance of professionals who had the opportunity to join the Multiprofessional Residency in Family Health. This was as a potential training focused on SUS.

[...] a little depends on one institution or the other, I graduated at [a public university in the south of the country] and there we have the competencies, compulsory internship in collective health, the physiotherapy in Nasf, so we have a foundation [...] so, we can have a greater understanding, and this varies greatly from one to the other [University]. (Physiotherapist2/Nasf-AB3)

[...] when I graduated, I worked directly in the psychiatric hospital, even though I worked in health care, I did not know what Nasf was. Then, I went to the Multiprofessional Residency. Here in the group [Nasf professionals], we have three former residents and we have more former residents in the network, we have nurses, pharmacists and I see how important this was, because when I entered the residency, I had no idea of what the Nasf was, my whole experience was in a psychiatric hospital, but that made a huge difference! These residents are entering the health area, working for the SUS, our training is for the SUS! So, I see it as such a rich process, so important, and in a certain way, it's a pride! (Social worker/Nasf-AB3)

Interviewees believe that the Coordination for Improvement of Higher Education Personnel (Portuguese acronym: CAPES) has offered training incentives that may contribute to breaking the biomedical focus. However, they emphasize the importance of adjustments, even of the physical structure of health units, for receiving health students and collaborating with universities in the teaching-service integration.

[...] I did not have in training, I guess now, at the macro level, federal, even CAPES is having more impact on health, within physical education [...] all physical education colleagues have already been invited to be speakers, talk about their professional experience. [...] but I do not have this [physical] structure to offer [...] as we will receive a trainee, train him/her, awaken a future professional for the network [...] create an internship program that can receive an academic and offer a foundation not only theoretical, but also grounded. At times, I did not even have a place to sit to discuss this. (Physical educator-AB3)

\section{Challenges in the daily life of Nasf-AB professionals: con- tinuing education as a power for success}

Nasf-AB professionals of SC feel little prepared to act according to the methodology it proposes. When referring to the professional trajectory, they mentioned the difficulty of some managers understanding the process and specificities of the work of the Nuclei, which leads them to reproduce individual and specialized clinical care (not as a team) according to their professional category. They also revealed aspects about the logistics of operationalizing the proposal.

[...] many professionals "fall" in the Nasf without the slightest notion of what it is. Before I came to work here, I worked at the Nasf in another municipality [...] when I arrived, I did not know what it was and gradually, with the professionals who were already there, I learned [...]. (Physiotherapist/Nasf-AB3)

[...] nor the teams [Family Strategy], neither we were we prepared [to act in Basic Care]. As the coordination changed - three different coordination teams have passed since I joined - we ended up staying idle inside the unit, because we were not going to work as a specialty. The teams did not know what our role would be, nor did we know [...] we started to attend, each one in their own space, working pretty much as a specialty, and now we have been three or four years in this process of teams understanding what our work really is. (Nutritionist/Nasf-AB1)

At the time when Nasf was created, I was manager of the municipality, I speak from experience, we did a project to have the Nasf, take advantage of the resource, at the time that was the understanding: you would use this resource to pay the professionals [specialists] who were already in the unit. Of course later, with time, we saw that it was not like that, then, it was adjusted. Nowadays, I still have difficulty, I talk about this with the current management, 
to understand what Nasf is, because they [managers] think the pharmacist stays there in the pharmacy, attending and delivering medication, that is not the goal, do you know what I mean? It is much more [...] then, at that time, this resource was to pay the employees who were already there, and nowadays we know it is not! (Pharmacist/Nasf-AB2)

The implementation of Nasf-AB is recent and the form of work is not yet legitimized, as is the case of the Family Strategy. Consequently, both managers and professionals still do not recognize their roles. Associated with these problems, is the lack of training/ qualification and guidelines that makes the performance of Nasf-AB difficult as an interprofessional team under the matrix organization. Sometimes their performance as specialists in Basic Care prevails.

[...] but what we observe at the Nasf meetings in [central municipality] is that it is like an improvisation and all municipalities are lost, because here, we have the privilege of who is Nasf, works only in Nasf [...] in many municipalities, the professional is placed in the Nasf and they work as specialists. (Physiotherapist/Nasf-AB2)

[...] this year, we were part of an introductory [course] that was a moment held there in the unit with all the new professionals, and every sector of the [Health] Secretariat was shown and each program was presented, each sector, and the Nasf professionals were introduced as well, we presented the Nasf, what Nasf is, what Nasf does and how it works. (Psychologist/Nasf-AB5)

[...] there are always new professionals, and the process always has to start again, talk about Nasf, what are the ordinances related to Nasf, what Nasf develops [...] doing the continuing education process and showing how our work is. (Social Worker/Nasf-AB5)

Interprofessional training is a necessary proposal for the performance of Nasf-AB, as well as the understanding and involvement of the manager in the process regarding the difficulties in the work and logic of the proposal. Nasf professionals emphasized the importance of involvement and exchange with other professionals, especially with nurses of the Family Strategy team, because this general practitioner commonly manages the Family Health teams, and needs to "work together" so the work of Nasf-AB professionals can be developed effectively.

In a way, it is a knowledge exchange, because it is the issue of training: I do not understand about nurses' work and they do not understand mine. (Social Worker/Nasf-AB2)

For our team, the difference of working in a unit where the coordination understands the work of Nasfis very clear. However, coordination alone is not enough, it needs to understand, be aware of the difficulties that we experience, too. Often, one understands how we should work, but thinks it's our responsibility! When the coordination understands that the responsibility of our work is also shared, it is much easier! In the team where, sometimes, a doctor has an understanding [about the work of Nasf-AB], especially if the nurse does not work together, things don't happen. (Physical educator/Nasf-AB3)

[...] most doctors already understand what Nasf is, newly graduated doctors work harder with this multidisciplinary and interdisciplinary issue. (Physiotherapist/Nasf-AB1)
[...] when the manager works together, which is more demanding, there is more participation [...] if the manager is participative and understands the work of Nasf, it goes better [...] (Social worker/Nasf-AB5)

With regard to continuing and permanent education, professionals in the state of Santa Catarina seek to understand and adopt the orientations that guide the performance of Nasf-AB, whether through web conferencing (Telehealth), exchange of experiences, research, and even postgraduate programs. However, they acknowledge the absence of a job and salary plan that encourages their quest. In addition, there are managers who support and others who do not encourage continuing education opportunities. In cases where training is not encouraged by the managers, Nasf professionals simply seek theoretical contribution for the work in ministerial guidelines.

[...] we do not receive training when we start working, about what Nasf is, we know there is a book, there are guidelines we can study and go after, but I think it's important, because in college we do not have this in depth [...] (Phyisiotherapist1/Nasf-AB3)

[...] since ljoined, in these three years, there was no training at state level. I think it's quite ok for me because of experience. [...] I was able to attend the telemedicine of Telehealth, but not a training for Nasf, I learned by reading [...] (Phyisiotherapist/Nasf-AB2)

[...] in 2015, was held the course of matrix support by the Ministry, because the Ministry itself saw that Nasf was not working as it should, I suppose [...] but in our personal training, we prepare for it: there are people with a master's degree, people with a postgraduate degree, but we are not encouraged in that direction, besides not gaining more for having this qualification. (Nutritionist/Nasf-AB1)

In relation to being graduated, I think it is almost unanimous, nobody left college and got here prepared, what you realize in the work of Nasf, is that there is "the man" who managed to stay inside Nasf, and went after training; some have a master's degrees, others did postgraduate studies, those who took courses, everyone went after it. (Physical educator/Nasf-AB1)

[...] the municipality has never denied to release employees to take a course, whether a specialization, whatever it is, it will depend very much on the professional, if there is interest or not, the municipality allows your leave, even presents at times, when we do not know [...] the municipality makes it available for us [...] (Speech-language pathologist/Nasf-AB 4)

I use UNA-SUS as well, the UNA-SUS courses [...] (Social worker/ Nasf-AB1)

The above statements also express that for professionals, the experiences offered by the daily work in Nasf-AB add knowledge. However, at the beginning, the main tools for better knowing the proposal are research and reading. In this same direction, other professionals emphasize that the Ministry of Health offers manuals and booklets that help, but are not very varied and didactic. A pedagogical notion of how to act is also missing, since graduation training not always includes these concepts.

[...] we read, [...] study, but we don't live that, don't have that experience of feeling part of a team; today we are going to have a formation 
group between teams and technicians: how are we going to work this group? Where are we going? Because it's one thing to do a group with the population, with pregnant women, and work on a specific subject, it's another thing to have a group of technicians and work something with the technicians [...] (Social worker/Nasf-AB2)

[...] in the Ministry, we receive many booklets of Basic Care, the Nasf booklets don't change much, because the Nasf manual is that, and that's what we can do, we'll go after by the Ministry. (Phyisiotherapist/Nasf-AB2)

The idea is to follow the guidelines, so we take great care to follow the guidelines, and modify some things throughout the process, mainly because of the very amount of residents [Multiprofessional Residency in Family Health] then, as we have many residents, the work process is changing more and more to get better. (Psychologist/Nasf-AB 4)

The testimonies reveal the vocation of Nasf professionals for teamwork, and that they have some tools in the training and in daily relations with the Family Health team for the development of work directed to interprofessionality. Among these tools, we highlight the collaborative practices and theoretical contributions on the specificities of collective health.

\section{DISCUSSION}

The formation of Nasf professionals was influenced by the Biomedical Model without inclusion of deep knowledge on the field of Collective Health. The core of knowledge and competence of health professions is an area of exclusive knowledge and practice, but with variable limits related to the context. On the other hand, the field of knowledge refers to a space of uncertain limits, in which each discipline and profession is supported by the others and common actions are shared between them for fulfilling their theoretical and practical attributions ${ }^{(6)}$. With such outlines, the work of Nasf-AB professionals has been oriented towards workers' performance in their own nucleus of knowledge and practice and close to the nucleus of the Family Health team, which embraces a common field of collective health care ${ }^{(14)}$.

The limits in the training of participants of this study result in difficulties in the daily context of their practices. In a convergent way, studies ${ }^{(15-18)}$ reveal the lack of interprofessional performance among professionals in Basic Care services, precisely because of the difficulty of collaboration and interaction between the different nuclei of knowledge and practices, a constant challenge for health professionals. These studies question how insufficient are the guidelines on the performance of Nasf-AB professionals in daily life, whether in individual or collective clinical care, or technical and pedagogical support. Matrix support is understood in different ways by teams of the Nuclei, and also by Family Health teams and managers, and this tool implies the construction of an integrated therapeutic project. The articulation between the basic team and supporters can be developed in three fundamental axes, namely: 1) joint interventions between the specialist and professionals of the reference team; 2 ) in situations that require specific attention to the knowledge nucleus of supporters, who can program specialized interventions for themselves and maintain contact with the reference team; 3 ) restriction to the exchange of knowledge and orientations between the team and supporters; from the dialogue by potentializing the reflection on the pedagogical practice, that is, acting as a training qualification instrument ${ }^{(19)}$.

As identified in another study ${ }^{(20)}$, the findings reveal controversies related to the role of each professional and the lack of references to support the practices in this new organization. Thus, is established a paradox, since there are concerns in defining guidelines for the "intra-area" performance of Nasf-AB, but the initiative is oriented precisely in the interprofessional articulation that implies collaboration between the different knowledge and nuclei of competence of each profession. Differentiating roles dilutes the idea of teamwork in the same way that specifying some professionals with more individual inputs/services deconstructs the idea of interprofessionality. For a researcher of the field, the challenge for Nasf-AB, would be to operate in all these dimensions by integrating them with the logic of an expanded vision of health production ${ }^{(21)}$.

Consistent with another study ${ }^{(2)}$, the present research raises the reflection on the relationship between the professionals' performance and the training. Professionals have acquired a broader view of health and collective work, possibly due to the reformulation of undergraduate health courses based on National Curricular Guidelines and movements directed to the reorientation of health training ${ }^{(11,22)}$. The changes require constant investments and represent important initiatives to strengthen interprofessional action. The results contextualize the distance to be covered in the training process in order to reach a formative approach in undergraduate health courses from this perspective. The World Health Organization (WHO) reports that Interprofessional Education "occurs when students from two or more professions learn about each other, with each other and among themselves to enable effective collaboration and improve health outcomes"(23).

Evidence indicates that IPE promotes the development of attitudes, knowledge, skills and behaviors that leads to collaborative practice, improvement of teamwork, development of respect and recognition of individuals' abilities. IPE allows professionals to use the full capacity of their training, and the WHO has made an effort to support countries in its implementation by organizing events, meetings, and stimulating partnerships with Canada, Spain, United Kingdom and the United States, where IPE already prevails in health courses. These initiatives strengthen the possibilities of professionals effective and collaborative action in articulated teams focused on people and communities. The importance of IPE in health education is increasingly recognized as a strategy capable of developing the competencies required by health care in the $21^{\text {st }}$ century ${ }^{(23-24)}$.

Nasf-AB professionals also seek support in strategies of continuing education, through research, exchange of experiences or access of guidelines via web conferences. They yearn for information given the commitment to the proposal of which they are protagonists. Commitment means being able to act (do) and reflect (think about action) from everyday problems, and these are conditions to make individuals the subjects of their praxis ${ }^{(25)}$. Such assumptions are the foundation of the National Policy of Continuing Education in Health (Portuguese acronym: PNEPS) from the perspective of the SUS, and the concept of Continuing Education in Health is anchored in meaningful learning, that is, the exchange of knowledge between subjects and its pedagogical applicability in health daily work. Learning and teaching are inseparable and imply reality change ${ }^{(25)}$. 
In this direction, the Ministries of Health and Education believe in policies that encourage the reorientation of training in health. Among these actions, multiprofessional residences and professional masters' programs are part of the transforming context of Basic Care and destined to encourage the transformation of the training process, generation of knowledge and provision of services to the population by anchoring in the proposal of reciprocal involvement between educational and service institutions. The pedagogical space does not end in the classroom and presupposes training in practice scenarios that are part of the world of work and rich in learning experiences. However, these spaces need to be explored pedagogically according to the critical-creative interposition of subjects involved in the process ${ }^{(26)}$.

For some authors ${ }^{(27-28)}$, the productive restructuring of health should happen through reorganizing the ways how professionals produce care, based on the revision of micro-policies of education and work (and education through work) processes ${ }^{(26)}$, and by incorporating technologies. Hence the need to reorganize routines and care flows, share decisions and divide technical power. This change process will only be possible with the protagonism of professionals involved and the management's support, since it requires the understanding and adhesion of all those involved in the daily routine of health production.

\section{Limitation of the study}

The study presented some limitations, such as the difficulty of gathering Nasf-AB professionals from all regions of the state, and analyzing the different social contexts where these teams work. This fact shows the need for studies that explore the theme with the aim of including other unaddressed aspects.

\section{Contributions to the collective health area}

Contributions to the area of collective health lie in movements that qualify the work of the Nuclei, such as gradual transformations in training by including contents of the field of collective health in pedagogical projects of courses, the presence of Continuing Education in Health as a tool for updating knowledge, and the offer of residences and professional masters' programs. These movements imply the integration of teaching and service with the necessary and proven promising connection between the worlds of work and health training.

\section{FINAL CONSIDERATIONS}

The training of Nasf-AB professionals is influenced by the Biomedical Model, which hinders interprofessional work. However, the orientation for the work of the Nasf in Basic Care, and the perspective of general training that includes a comprehensive field of knowledge aimed at prevention and promotion actions based on interdisciplinary and intersectoral actions, enhance interprofessional practice. In this sense, the continuing education of Nasf-AB professionals and Family Health teams emerges as a singular way of coping with the limits of daily work.

The obstacles faced by Nasf professionals arise from relatively recent movements of health change, of which this tool is part. Nasf-AB still generates strangeness in professionals, because its theoretical framework is anchored in health production through matrix and interprofessional networks with the aim of increasing accessibility, resolution and integrality of SUS care.

The prospect that "supporters" realize that they need support is revealing, which is understandable, since the Nasf-AB has the task of working with generalist teams of Family Health/Basic Care without being part of them. On the other hand, taking part would be essential to share knowledge and effectively exercise interprofessionality.

\section{FUNDING}

Santa Catarina Research Foundation (FAPESC) - grant term number 2016TR2209, contemplated in the public call FAPESC no.10/2015 Support to the Research Program for SUS (PPSUSShared Health Management).

\section{REFERENCES}

1. Machado CV, Lima LD. Políticas e sistemas de saúde na América Latina: identidade regional e singularidades nacionais. Cad Saúde Pública [Internet]. 2017 [cited 2018 May 07];33(2):e00068617. Available from: http://www.scielo.br/pdf/csp/v33s2/1678-4464-csp-33-s2-e00068617.pdf

2. Vendruscolo C, Trindade LL, Kleba ME, Prado ML. Rethinking the Health Care Model through the reorientation of training. Rev Bras Enferm [Internet]. 2018 [cited 2018 Dec07];71(4):1580-88. Available from: http://www.scielo.br/pdf/reben/v71s4/0034-7167-reben-71-s4-1580.pdf

3. Ministério da Saúde (BR). Secretaria de Atenção à Saúde. Departamento de Atenção Básica. Núcleo de Apoio à Saúde da Família. Brasília: Ministério da Saúde, 2014.

4. Oliveira MM, Campos GWS. Apoios matricial e institucional: analisando suas construções. Ciênc Saúde Colet [Internet]. 2015 [cited 2018 Apr 10];20(1):229-38. Available from: http://www.scielo.br/pdf/csc/v20n1/pt_1413-8123-csc-20-01-00229.pdf

5. World Health Organization (WHO). Framework for action on interprofessional education \& collaborative practice. Geneva: World Health Organization [Internet]. 2010 [cited 2018 Apr 10] Available from: https://apps.who.int/iris/bitstream/handle/10665/70185/WHO_HRH_ HPN_10.3_eng.pdf;jsessionid=C43682F49449B6F5055E9FC49E4F714B?sequence=1

6. Campos GWS, Figueiredo MD, Pereira Jr N, Castro CP. A aplicação da metodologia Paideia no apoio institucional, no apoio matricial e na clínica ampliada. Interface [Internet]. 2014[cited 2018 Apr 25];18(1):983-95. Available from: http://www.scielo.br/pdf/icse/v18s1/1807-5762icse-18-1-0983.pdf

7. Souza TP; Carvalho SR. Apoio territorial e equipe multirreferencial: cartografias do encontro entre o apoio institucional e a redução de danos nas ruas e redes de Campinas, SP, Brasil. Interface [Internet]. 2014 [cited 2018 Sep 24];18(1):945-56. Available from: http://www.scielo.br/pdf/ 
icse/v18s1/1807-5762-icse-18-1-0945.pdf

8. Engstrom EM, Motta Jl, Venâncio SA. Training of professionals in post-graduation courses in public health and primary healthcare in the municipality of Rio de Janeiro, Brazil. Ciênc Saúde Colet [Internet]. 2016 [cited 2018 Apr 10];21(5):1461-70. Available from: http://www. scielo.br/pdf/csc/v21n5/en_1413-8123-csc-21-05-1461.pdf

9. Araújo TAM, Vasconcelos ACCP, Pessoa TRRF, Forte FDS. Multiprofessionality and interprofessionality in a hospital residence: preceptors and residents' view. Interface. 2017;21(62):601-13. doi: 10.1590/1807-57622016.0295

10. D'Amour D, Goulet L, San Martín-Rodrigues L, et al. A model and typology of collaboration between professionals in healthcare organizations. BMC Health Services Research [Internet]. 2008 [cited 2018 Ago 02];8, 188. Available from: https://bmchealthservres. biomedcentral.com/articles/10.1186/1472-6963-8-188

11. Reis ML, Medeiros M, Pacheco LR, Caixeta CC. Avaliação do trabalho multiprofissional do Núcleo de Apoio à Saúde da Família (NASF). Texto Contexto Enferm [Internet]. 2016 [cited 2018 Apr 25];25(1):e2810014. Available from: http://www.scielo.br/pdf/tce/v25n1/pt_0104-0707tce-25-01-2810014.pdf

12. Yin RK. Estudo de caso: planejamento e métodos. 5ed. Porto Alegre: Bookman, 2015.

13. Minayo MCS. O desafio do conhecimento: pesquisa qualitativa em saúde. 14ª ed. São Paulo: Hucitec; 2014.

14. Vendruscolo C, Ferraz F, Trindade L, Tesser CD. Family Health Support Center: an intersection between primary and secondary health care. Texto Contexto Enferm. 2019;28:e20170560. doi: 10.1590/1980-265x-tce-2017-0560

15. Andrade AF, Lima MM, Monteiro NP, Silva VL. Evaluation of the shares of Speech Therapy in the NASF in Recife. Audiol Commun Res [Internet]. 2014 [cited 2018 Apr 25];19(1):52-60. Available from: http://www.scielo.br/pdf/acr/v19n1/en_2317-6431-acr-19-1-0052.pdf

16. Ferro LF, Silva EC, Zimmermann AB, Castanharo RCT, Oliveira FRL. Interdisciplinaridade e intersetorialidade na Estratégia Saúde da Família e no Núcleo de Apoio à Saúde da Família: potencialidades e desafios. Mundo Saúde [Internet]. 2014 [cited 2018 Apr 25];38(2):129-38. Available from: https://www.saocamilo-sp.br/pdf/mundo_saude/155562/A01.pdf

17. Barros NF, Spadacio C, Costa MV. Trabalho interprofissional e as Práticas Integrativas e Complementares no contexto da Atenção Primária à Saúde: potenciais e desafios. Saúde Debate [Internet] 2018 [cited 2018 Dez 20];42(1):163-173. Available from: http://www.scielo.br/pdf/ sdeb/v42nspe1/0103-1104-sdeb-42-spe01-0163.pdf

18. Martinez JFN, Silva MS, Silva AM. O Núcleo de Apoio à Saúde da Família em Goiânia (GO):percepções dos profissionais e gestores. Saúde Debate [Internet] 2016 [cited 2018 Apr 25];40(110):95-106. Available from: http://www.scielo.br/pdf/sdeb/v40n110/0103-1104sdeb-40-110-0095.pdf

19. Campos GWS, Domitti AC. Apoio matricial e equipe de referência: uma metodologia para gestão do trabalho interdisciplinar em saúde. Cad Saude Publica [Internet]. 2007 [cited 2018 Apr 10];23(2):399- 407. Available from: http://www.scielo.br/pdf/csp/v23n2/16.pdf

20. Correia PCL, Goulart PM, Furtado JP. A avaliabilidade dos Núcleos de Apoio à Saúde da Família (NASF). Saúde Debate [Internet]. 2017 [cited 2018 May 07];41(esp):345-59. Available from: http://www.scielo.br/pdf/sdeb/v41nspe/0103-1104-sdeb-41-nspe-0345.pdf

21. Campos GWS. Saúde Mental e Atenção Primária: apoio matricial e Núcleos de Apoio à Saúde da Família. In: Nunes M, Ladndim ELP. Saúde Mental na Atenção Básica: política e cotidiano. Salvador: Edufba, 2016.

22. Nakamura CL, Leite SN. A construção do processo de trabalho no Núcleo de Apoio à Saúde da Família: a experiência dos farmacêuticos em um município do sul do Brasil. Ciênc Saúde Colet [Internet]. 2016 [cited 2018 Apr 25];21(5):1565-72. Available from: http://www.scielo.br/ $\mathrm{pdf} / \mathrm{csc} / \mathrm{v} 21 \mathrm{n} 5 / 1413-8123-\mathrm{csc}-21-05-1565 . \mathrm{pdf}$

23. Mikael SSE, Cassiani SHDB, Silva FAM. The PAHO/WHO Regional Network of Interprofessional Health Education. Rev Latino-Am Enfermagem [Internet]. 2017 [cited 2018 May 07];25: e2866. Available from: http://www.scielo.br/pdf/rlae/v25/0104-1169-rlae-25-e2866.pdf

24. Lie DA, Forest CP, Kysh L, Sinclair L. Interprofessional education and practice guide No. 5: Interprofessional teaching for prequalification students in clinical settings. J Interprof Care [Internet]. 2016 [cited 2018 May 07];30(3):324-30. Available from: https://www.ncbi.nlm.nih. gov/pubmed/271525366

25. Vendruscolo C, Ferraz F, Prado ML, Kleba ME, Reibnitz KS. Teaching-service integration and its interface in the context of reorienting health education. Interface [Internet]. 2016 [cited 2018 May 07];20(59):1015-25. Available from: http://www.scielo.br/pdf/icse/v20n59/en_18075762-icse-1807-576220150768.pdf

26. Vendruscolo C, Prado ML, Kleba ME. Reorientação do Ensino na Saúde: para além do quadrilátero, o prisma da educação. Reflex Ação [Internet]. 2016 [cited 2018 May 07];24(3):246-60. Available from: http://online.unisc.br/seer/index.php/reflex/index

27. Pires D. Reestruturação produtiva e consequências para o trabalho em saúde. Rev Bras Enferm [Internet]. 2000 [cited 2018 May 07];53(2):251-263. Available from: http://www.scielo.br/pdf/reben/v53n2/v53n2a10.pdf

28. Merhy EE, Franco TB. Reestruturação produtiva em saúde. In: Pereira IB, Lima JCF, editors. Dicionário da Educação Profissional em Saúde. $2^{a}$ ed. Rio de Janeiro: EPSJV, 2008. 